\title{
Efficacy Evaluation of Seed-Coating Compounds Against Cereal Cyst Nematodes and Root Lesion Nematodes on Wheat
}

Jiang-Kuan Cui, Wen-Kun Huang, and Huan Peng, State Key Laboratory for Biology of Plant Diseases and Insect Pests, Institute of Plant Protection, Chinese Academy of Agricultural Sciences, Beijing 100193, China; Yan Lv, Xuchang Plant Protection Station, Xuchang, Henan 461000, China; Ling-An Kong, State Key Laboratory for Biology of Plant Diseases and Insect Pests, Institute of Plant Protection, Chinese Academy of Agricultural Sciences, Beijing 100193, China; Hui-Xia Li, Grassland Science Institute of Gansu Agricultural University, Lanzhou 730070, China; Shu-Jie Luo, State Key Laboratory for Biology of Plant Diseases and Insect Pests, Institute of Plant Protection, Chinese Academy of Agricultural Sciences, Beijing 100193, China; Yan Wang, Xuchang Plant Protection Station, Xuchang, Henan 461000, China; and De-Liang Peng, State Key Laboratory for Biology of Plant Diseases and Insect Pests, Institute of Plant Protection, Chinese Academy of Agricultural Sciences, Beijing 100193, China

\begin{abstract}
Cereal cyst nematodes (Heterodera avenae and $\mathrm{H}$. filipjevi) and root lesion nematodes (Pratylenchus spp.) have been found to infect cereals in 16 provinces of China. To develop a nematicide that effectively controls nematodes, two novel chemical products, methylene bis thiocyanate (MBT) and MBT + thiamethoxam (MTT); four common pesticides, fipronil + chlorpyrifos (FIC), emamectin benzoate, imidacloprid, and Bacillus thuringiensis; and one fungicide, iprodione, were tested as seed coatings for the control of cereal cysts and root lesion nematodes from 2013 to 2015. Wheat seeds were treated with these seven seed coatings before sowing, and changes in the numbers of Heterodera spp. and Pratylenchus spp. were

recorded during three different growth stages. Wheat yields were also compared after harvest. All treatments reduced the numbers of Pratylenchus in wheat and of cysts and eggs of Heterodera in the soil compared with the untreated control. Among the treatments, application of MTT or FIC was more effective than that of the other treatments for nematode control, and the other treatments had similar effects. The results of this study have demonstrated that MTT and FIC applied as seed treatments effectively reduce the number of cysts, inhibit the reproduction of Heterodera and Pratylenchus, and enhance wheat yields. MTT and FIC are thus suitable for controlling nematodes on wheat under natural field conditions.
\end{abstract}

The most globally recognized and economically important wheat nematodes are the cereal cyst nematodes (CCNs; Heterodera avenae, $H$. filipjevi, and $H$. latipons), and the other nematodes considered economically important to wheat production systems are the migratory endoparasitic root lesion nematodes (RLNs; Pratylenchus spp.) (Nicol et al. 2011). Pratylenchus spp. causes damage to many crops, and this damage is often underestimated. Yield losses of wheat caused by RLNs have been reported at rates of up to $30 \%$ in Australia (Vanstone et al. 2008). H. avenae and $H$. filipjevi are the two main $\mathrm{CCN}$ species occurring in China. H. avenae was first reported in China in 1989 and was subsequently reported in 16 provinces. Over 4 million ha of the major wheat-producing regions are infested by CCNs (Cui et al. 2015). Yield losses of 16 to 55\% have occurred in China when the density of $H$. avenae has exceeded 10 eggs g $^{-1}$ of soil (Hou et al. 2012). Peng et al. (2010) first described $H$. filipjevi in Xuchang County of Henan Province, and it was later found in Anhui Province (Peng et al. 2016). Grain yield loss has been demonstrated at very low population densities of $H$. filipjevi in Iran, reaching a maximum loss of $48 \%$ at an initial density of 20 eggs and $\mathrm{J}_{2} \mathrm{~g}^{-1}$ of soil (Hajihasani et al. 2010).

Nematodes are difficult to control because they are soilborne and are not easily detectable in the field. Currently, application of chemical nematicides is among the primary means of controlling plant parasitic nematodes. The most widely used nematicides are organophosphates and carbamates, such as ethoprop, fenamiphos, fosthiazate, and oxamyl (Rich et al. 2004). In greenhouse tests and field trials, application of emamectin benzoate (EMB) (1\% EC, a.i.) furrow at doses of 75,100 , and $150 \mathrm{~g} \mathrm{ha}^{-1}$ increased the marketable crop yield from 37 to $81 \%$ compared with an untreated control, with the best results obtained

Corresponding author: De-Liang Peng; E-mail: dlpeng @ippcaas.cn

J.-K. Cui, W.-K. Huang, and H. Peng contributed equally to this work.

Accepted for publication 10 October 2016.

C 2017 The American Phytopathological Society at the highest dose of EMB (Cheng et al. 2015). In addition, direct application of imidacloprid (IMI) $\left(5 \mathrm{~g} \mathrm{~kg}^{-1} \mathrm{GR}\right)$ to soil reduced the population of Aphelenchoides fragariae by $62 \%$ relative to the control (Jagdale and Grewal 2002). Further, methylene bis thiocyanate (MBT) and MBT + thiamethoxam (MTT) seed coatings have been demonstrated to be effective for controlling $H$. avenae, reducing cysts by 53 and $56 \%$ and increasing wheat yields by 38 and $19 \%$, respectively (Hao et al. 2014). Further, iprodione (IPR), marketed for use as a nematicide, has been shown to effectively reduce early-season galling on tomato (Solanum lycopersicum) caused by M. incognita (Becker and Ploeg 2012, 2013; Moore and Lawrence 2010). Bacillus thuringiensis (BT) is a bacterium that also exhibits nematicidal activity (Yu et al. 2015). Devidas and Rehberger (1992) have confirmed that BT produces toxins capable of limiting nematode multiplication in the soil. The spore/crystal proteins of BT isolates exhibit high nematicidal activity, with mortality rates ranging from 86 to $100 \%$ (Mohammed et al. 2008). The coating of seeds with pesticides and fungicides has been shown to promote plant growth, increase wheat yield, and prevent diseases and pest infestation (Bi et al. 2014). For decades, chemical nematicides have played a prominent role in the management of nematodes, and such chemicals are effective, with a rapid onset (Haydock et al. 2006). Methyl bromide was widely used as a fumigant nematicide before it was restricted due to its detrimental effects on the ozonosphere (Kearn et al. 2014). Ideally, a pesticide should be toxic only to the target organisms; however, fumigants are a class of pesticides with broad biocidal activity, affecting many nontarget soil organisms (Dungan et al. 2003). The high cost and toxicity of these nematicides have also limited their use. Therefore, the search for novel chemotypes of nematicides that are safer, environmentally friendly, and nematode specific has become increasingly urgent.

The objectives of this study were as follows: i) to evaluate the impacts of natural infestations of CCNs and RLNs on the growth and yield of wheat (Triticum aestivum); ii) to evaluate the efficacies of seven pesticides applied as wheat seed treatments for the control of CCNs and RLNs; and iii) to evaluate the labor and cost savings associated with replacement of the current nematode control strategies with seed treatments. 


\section{Materials and Methods}

Experimental field conditions. Two experiments were conducted in different fields (F1 and F2) from 2013 to 2014 and from 2014 to 2015 in Henan Province, China, an area with a continental monsoon climate. F1 $\left(35^{\circ} 04^{\prime} 53^{\prime \prime} \mathrm{N}, 113^{\circ} 27^{\prime} 39^{\prime \prime} \mathrm{E}\right)$ was selected with intermediate densities of $H$. avenae and $P$. thornei. The soil of F1 was a silty loam with an organic matter content of $20 \mathrm{~g} \mathrm{~kg}^{-1}$ of soil, a $\mathrm{pH}$ of 7.2, a total $\mathrm{N}$ concentration of $1.1 \mathrm{~g} \mathrm{~kg}^{-1}$ of soil, and a cation exchange capacity of $19.2 \mathrm{cmol}(+) \mathrm{kg}^{-1}$ of soil. F2 $\left(34^{\circ} 03^{\prime} 14^{\prime \prime} \mathrm{N}\right.$, $\left.113^{\circ} 44^{\prime} 29^{\prime \prime} \mathrm{E}\right)$ was selected with high densities of $H$. filipjevi, $P$. thornei, and P. neglectus. The soil of F2 was a loam with an organic matter content of $13.7 \mathrm{~g} \mathrm{~kg}^{-1}$ of soil, a $\mathrm{pH}$ of 7.3 , a total $\mathrm{N}$ concentration of $0.8 \mathrm{~g} \mathrm{~kg}^{-1}$ of soil, and a cation exchange capacity of $18.4 \mathrm{cmol}(+) \mathrm{kg}^{-1}$ of soil.

Experimental treatments and design. Six treatments (MBT, MTT, EMB, IMI, BT, and tap water) were tested in 2013 to 2014 on field $\mathrm{F} 1$, infested by $H$. avenae and $P$. thornei. Eight treatments (MBT, MTT, EMB, FIC, IMI, BT, IPR, and tap water) were tested in 2014 to 2015 on field F2, infested by H. filipjevi, P. thornei, and $P$. neglectus (Table 1). The plots were $70 \mathrm{~m}$ long and $3 \mathrm{~m}$ wide (18 plant rows), and the wheat variety Aikang 58 was used. Three replicates were arranged as randomized complete blocks. Diammonium phosphate, urea, and $51 \%$ triple potassium sulfate were applied at plowing at rates of 150,245 , and $225 \mathrm{~kg} \mathrm{ha}^{-1}$. Urea $\left(120 \mathrm{~kg} \mathrm{ha}^{-1}\right)$ was applied at the wheat growth stage Feekes 3.0 (Miller 1999) for tillering. Wheat seeds were coated with MBT, MTT, EMB, FIC, IMI, BT, IPR, or tap water (Table 1). The nematicides and water were mixed with the seeds using an RK-003 seed dresser (Ruikuang Machinery Co., Ltd., Ningyang, Shandong Province, China) 1 day before planting. Twenty-five kilograms of wheat seeds were mixed with the different treatments in batches. The nematicides were quantitatively diluted to 1 liter with tap water and added slowly to the working seed dresser. The nematicide solution was shaken well for $15 \mathrm{~min}$ before each treatment, and the seed dresser was automatically cleaned between the treatments, according to the manufacturer's instructions. Seeds were planted using a 2BX-9 automatic drill (Nonghaha Machinery Group Co., Ltd., Shijiazhuang, Hebei Province, China) equipped with a disc coulter and nine openers with $14.5-\mathrm{cm}$ spacing. The seeds were sown at a rate of $14 \mathrm{~kg} 0.067 \mathrm{ha}^{-1}$ into moist soil at a depth of 3 to $5 \mathrm{~cm}$ and a seed-zone temperature of 14 to $16^{\circ} \mathrm{C}$.

The initial population $\left(P_{\mathrm{i}}\right)$ densities of nematodes in the experimental area were determined by collecting three samples per plot in a zigzag pattern. Similarly, the final population $\left(P_{\mathrm{f}}\right)$ densities of mature brown cysts in the field were determined after harvesting. Each sample was a composite of 15 soil cores $2.5 \mathrm{~cm}$ in diameter by $35 \mathrm{~cm}$ in depth. The collected soil cores were thoroughly mixed, and three $100-\mathrm{cm}^{3}$ subsamples were removed. Cysts were extracted from the soil by wet sieving and sucrose flotation centrifugation procedures (Riggs et al. 2000). Five mature cysts from each sample were crushed with a ground-glass homogenizer to release eggs. The egg suspension $(10 \mathrm{ml})$ was stirred, and three $1-\mathrm{ml}$ samples were removed and placed in a counting dish. The number of cysts and eggs was determined using a stereomicroscope. The $P_{\mathrm{i}}$ densities of Pratylenchus spp. in the experimental area were determined by collecting three composite samples (45 soil cores) per plot, and the $P_{\mathrm{f}}$ densities of Pratylenchus spp. were determined at the wheat growth stages Feekes 5.0 and Feekes 10.3. Pratylenchus spp. were extracted from the soil subsamples using the Baermann funnel method (Graeff-Teixeira et al. 1997). Two hundred milliliters of each soil subsample was used for extraction, which was performed for $36 \mathrm{~h}$ at room temperature, and the sediment was collected twice (Mao et al. 2004). The Pratylenchus spp. suspension $(20 \mathrm{ml})$ was then stirred, and three 1-ml samples were removed and placed in a counting dish for determination of the number of Pratylenchus spp. using a stereomicroscope. We also assessed the effects of the treatments on juvenile CCNs by counting the numbers of third (J3)- and fourth (J4)-stage juveniles in wheat roots. The J3- and J4-stage juveniles per gram of roots were counted at the wheat growth stage Feekes 8.0 in 2014. Ten wheat plants were randomly selected per plot, and the roots were then carefully washed and stained with acid fuchsin (Byrd et al. 1983).

Normal plant growth conditions for irrigation, fertilization, and the control of weeds, diseases, and insects were maintained by field workers. Forty percent omethoate and $15 \%$ triadimefon were used for controlling wheat aphids and wheat rust at the wheat growth stage Feekes 10.0. The agronomic characteristics of the treated wheat plants (plant height, spike number per square meter, spike grain number, thousand-seed weight, and grain yield per square meter) were compared with those of the untreated controls after the harvesting of three $6.66-\mathrm{m}^{2}$ areas of each plot randomly using a KTY-100 seed sheller (Xinchang Machinery Group Co., Ltd., Weihui, Henan Province, China).

Economic impacts. The economic impacts of the nematicide seed treatments were estimated by calculating the differences in grain yield between the plots planted with treated seeds and those planted with untreated seeds from 2013 to 2015 (Table 2). Yield increases (calculated as $\mathrm{kg} 0.067 \mathrm{ha}^{-1}$ ) were multiplied by the mean monthly farm gate price (CNY per kg) in Henan Province during the month immediately following the harvest at that location. The net profit or loss associated with a yield increase or decrease was calculated using the commercial price of application of the appropriate treatment with a commercial seed conditioner during the year in which the treatment was applied (Smiley et al. 2012).

Statistical analysis. The following equations were used in statistical analysis:

Reproduction factor $(\mathrm{RF})=P_{\mathrm{f}} / P_{\mathrm{i}}$;

Reduction of soil cyst population over control $(\mathrm{ROC})=[$ cyst $(\mathrm{egg})$ number for control - cyst (egg) number for treatment] $\times 100 \% /$ cyst (egg) number for control;

Yield increase rate $(\%)=($ yield of treatment - yield of control $) \times$ $100 \%$ / yield of control;

The RF and ROC index were applied to assess the efficacies of the chemicals on the nematodes (Jagdale and Grewal 2002).

The growth indices of wheat, grain yield, cyst number, egg number per cyst, and RLN number under field conditions were used in statistical analysis. Analysis of variance (ANOVA) was performed individually for each field experiment. The significant differences

Table 1. Tested chemical formulations, sources, dosages and target organisms ${ }^{\mathrm{w}}$ in 2013 and 2014

\begin{tabular}{|c|c|c|c|}
\hline Nematicide & Formulations $^{x}$ & Source & $\operatorname{Dosage}^{\mathrm{y}}(\mathrm{ml} / \mathrm{kg})$ \\
\hline MBT & $1.0 \%$ Methylene bis thiocyanate FSC & Gansu Agricultural University, $\mathrm{CN}$ & 25 \\
\hline MTT & 1.0\% Methylene (bis)thiocyanate/10\%Thiamethoxam FSC & Gansu Agricultural University, CN & 25 \\
\hline EMB & 5.7\% Emamectin benzoate ME & Shenzhen Noposion Agrochemical Co., LTD, CN & 10 \\
\hline IMI & $60 \%$ Imidacloprid FSC & Bayer CropScience, Hangzhou City, CN & 5 \\
\hline $\mathrm{BT}$ & Bacillus thuringiensis (16000IU/mg) WP & Huazhong Agricultural University, $\mathrm{CN}$ & $35^{\mathrm{y}}$ \\
\hline $\mathrm{FIC}^{\mathrm{z}}$ & $3 \%$ Fipronil/15\% Chlorpyrifos FSC & Beijing Yoloo Pesticide Co., LTD, CN & 10 \\
\hline $\mathrm{IPR}^{\mathrm{z}}$ & $50 \%$ Iprodione SC & Bayer CropScience, Hangzhou City, CN & 15 \\
\hline Control & Tap-water & & \\
\hline
\end{tabular}

\footnotetext{
${ }^{\text {w }}$ Target nematodes were $H$. avenae and P. thornei in 2013, and H. filipjevi, P. thornei, and P. neglectus in 2014.

${ }^{x}$ FSC, flowable concentrate for seed coating; ME, microemulsion; WP, water power; SC, suspension concentrate.

y BT dosage was calculated grams of product per kilograms.

${ }^{\mathrm{z}}$ FIC and IPR were tested in 2014 only.
} 
among the treatments were determined with the least significant difference (LSD) test using SPSS 12.0 software (SPSS Inc.) $(P \leq 0.05)$.

\section{Results}

Effects of nematicides on nematode density. Cysts of CCNs. All of the nematicides tested in the 2013 to 2015 trials were effective in controlling $H$. avenae and $H$. filipjevi. In 2013, the postharvest cyst densities did not significantly differ among the nematicide treatments, but all of the treatment plots showed significant differences compared with the control plots. MBT showed the greatest ROC value of $63.5 \%$ on H. avenae; however, the RF of MTT was the lowest (0.6), with an ROC value of $61.9 \%$. IMI exhibited the lowest ROC value of $47.6 \%$ (Table 3 ). The density of cysts in the untreated group increased by $50 \%$ compared with the initial density. In 2014, the treatments achieved significant control of $H$. filipjevi, as determined by the postharvest cyst densities. The density of cysts in the untreated group increased by $137.9 \%$ compared with the initial density. The cyst RFs in the plots treated with MTT, MBT, and FIC were 0.8 , 0.9 , and 0.9. MTT and FIC had the greatest ROC values of 60.7 and $62.0 \%$, respectively.

Eggs of CCNs. The influences of seed coating on the mean number of eggs in cysts were assessed. The numbers of eggs in the cysts in the treated plots were all significantly lower than those in the cysts in the control plots (Table 4). MTT had the greatest ROC value of $28.8 \%$ against the eggs compared with the other treatments in both fields and during both years, followed by MBT and FIC, with ROC values of 27.5 and $26.6 \%$. Accordingly, MTT exhibited the lowest RF value of 0.8 during both years.

Juveniles of CCNs in roots. The mean numbers of $\mathrm{J} 3$ and $\mathrm{J} 4$ juveniles observed in roots treated with MTT and FIC were 13.2 and 17.6, which were 2.9- and 2.3-fold lower than that in roots treated with CK of 37.8 (Fig. 1). There was no significant difference in the invasion of juveniles in the roots between the BT and CK treatments. In brief, according to the mean values for the invasion of juveniles in the roots, the MTT and FIC treatments outperformed the other treatments, followed by the MBT treatment.

Pratylenchus spp. Soil populations of Pratylenchus spp. (P. thornei and $P$. neglectus) were measured three times according to the wheat development stage. In 2013, the density of $P$. thornei in the untreated group increased by factors of 1.2 and 3.0 at Feekes growth stages 5.0 and 10.3, respectively, compared with the initial population density. EMB and MTT were the most effective chemicals against $P$. thornei, with ROC values of 28.1 and $26.5 \%$, respectively. In 2014, the density of Pratylenchus spp. in the untreated group increased by factors of 1.2 and 2.4 at the growth stages 5.0 and 10.3. EMB and MTT were the most effective chemicals for controlling
Pratylenchus spp., with ROC values of 34.2 and $33.4 \%$, respectively. No significant differences in control efficiency were observed between EMB and MTT, and the MBT and FIC control efficiencies were slightly lower, with ROC values of 30.6 and $29.3 \%$. BT was the least effective at suppressing the growth of Pratylenchus spp. (Table 5).

Wheat yield and economic benefits. There were no differences in the spike grain number among the treatments and untreated control (Table 2). The seed coating treatments promoted plant growth, with IMI exhibiting significantly greater effects than the other treatments. IPR, MTT, and IMI had powerful effects on tillering, showing significant differences in the wheat spike numbers per square compared with the other treatments. The grain yields per square of the treatment groups all significantly differed from that of the untreated control group (Table 2). In 2013, MTT provided the greatest yield increase at $710 \mathrm{~g} \mathrm{~m}^{-2}$, and with an increase rate of $16.9 \%$. In 2014 , all of the treatments except for BT resulted in a significantly higher thousand-seed weight compared with that in the untreated group. IPR, MTT, and FIC showed good efficacies for increasing the wheat yield.

The net incomes obtained using the different treatments showed a trend similar to that of the grain yields. MTT resulted in the highest additional gross income of $135 \mathrm{CNY}$ per 0.067 ha, which was $16.9 \%$

Table 3. Effects of seed treatments on cysts in fields naturally infested with H. avenae (2013) and H. filipjevi (2014) ${ }^{\mathrm{z}}$

\begin{tabular}{llcccc}
\hline & & \multicolumn{3}{c}{ Number of cysts in 100 ml of soil } & \\
\cline { 3 - 5 } Year & Treatment & Seeding Time & Harvesting Time & RF & ROC (\%) \\
\hline 2013 & MBT & $6.6 \pm 0.89 \mathrm{ab}$ & $4.6 \pm 2.07 \mathrm{a}$ & 0.70 & 63.49 \\
& MTT & $8.2 \pm 1.64 \mathrm{~b}$ & $4.8 \pm 1.52 \mathrm{a}$ & 0.58 & 61.90 \\
& EMB & $7.8 \pm 1.30 \mathrm{~b}$ & $5.4 \pm 1.03 \mathrm{a}$ & 0.69 & 57.14 \\
& IMI & $7.2 \pm 1.30 \mathrm{ab}$ & $6.6 \pm 1.14 \mathrm{a}$ & 0.92 & 47.62 \\
& BT & $5.6 \pm 2.07 \mathrm{a}$ & $5.6 \pm 1.00 \mathrm{a}$ & 1.00 & 55.56 \\
& Control & $8.4 \pm 1.14 \mathrm{~b}$ & $12.6 \pm 1.14 \mathrm{~b}$ & 1.50 & \\
MBT & $16.8 \pm 1.30 \mathrm{~b}$ & $14.2 \pm 1.30 \mathrm{~cd}$ & 0.85 & 48.55 \\
& MTT & $13.4 \pm 2.07 \mathrm{a}$ & $10.6 \pm 1.14 \mathrm{a}$ & 0.79 & 61.59 \\
& EMB & $13.2 \pm 2.59 \mathrm{a}$ & $11.8 \pm 1.64 \mathrm{ab}$ & 0.89 & 57.25 \\
& IMI & $12.2 \pm 1.58 \mathrm{a}$ & $12.8 \pm 1.48 \mathrm{bc}$ & 1.05 & 53.62 \\
& BT & $14.4 \pm 3.58 \mathrm{ab}$ & $15.6 \pm 1.34 \mathrm{de}$ & 1.08 & 43.48 \\
& FIC & $11.8 \pm 2.77 \mathrm{a}$ & $10.5 \pm 2.28 \mathrm{a}$ & 0.89 & 61.96 \\
& IPR & $12.1 \pm 1.87 \mathrm{a}$ & $11.2 \pm 0.83 \mathrm{ab}$ & 0.93 & 55.79 \\
& Control & $11.6 \pm 2.41 \mathrm{a}$ & $27.6 \pm 2.19 \mathrm{e}$ & 2.38 & \\
\hline
\end{tabular}

${ }^{\mathrm{z}}$ Mean \pm standard deviation of the mean. The same letter within a column for each year indicates no significant difference at $P \leq 0.05$.

Table 2. Effects of seed treatments on agronomic characteristics of wheat and on net profit ${ }^{\mathrm{w}}$

\begin{tabular}{|c|c|c|c|c|c|c|c|c|}
\hline Year & Treatment & Plant height (cm) & Spike number per $\mathbf{m}^{2}$ & NFGPx & TKW $^{\mathbf{y}}(\mathrm{g})$ & Yield per $\mathrm{m}^{2}\left(\mathrm{~g} \mathrm{~m}^{-2}\right)$ & $\begin{array}{c}\text { Yield } \\
\text { increase }(\%)\end{array}$ & Net profit $(\mathrm{CNY})^{\mathrm{z}}$ \\
\hline \multirow[t]{6}{*}{2013} & MBT & $56.2 \pm 2.38 \mathrm{~b}$ & $577.7 \pm 31.82 \mathrm{bc}$ & $33.2 \pm 6.53 \mathrm{a}$ & $45.7 \pm 0.67 \mathrm{a}$ & $656.2 \pm 48.85 \mathrm{~b}$ & 10.1 & 93 \\
\hline & MTT & $57.8 \pm 1.64 \mathrm{~b}$ & $634.0 \pm 19.67 \mathrm{~d}$ & $34.2 \pm 5.76 \mathrm{a}$ & $45.9 \pm 0.72 \mathrm{a}$ & $710.0 \pm 15.28 \mathrm{c}$ & 16.9 & 135 \\
\hline & EMB & $58.2 \pm 1.92 \mathrm{~b}$ & $597.3 \pm 12.89 \mathrm{bc}$ & $31.4 \pm 8.70 \mathrm{a}$ & $45.7 \pm 1.23 \mathrm{a}$ & $649.2 \pm 9.52 b$ & 9.1 & 90 \\
\hline & IMI & $64.8 \pm 1.48 \mathrm{c}$ & $616.3 \pm 17.21 \mathrm{~cd}$ & $33.4 \pm 6.19 a$ & $45.8 \pm 1.24 \mathrm{a}$ & $698.0 \pm 9.38 \mathrm{c}$ & 15.4 & 115 \\
\hline & $\mathrm{BT}$ & $57.0 \pm 1.87 \mathrm{~b}$ & $556.0 \pm 43.59 \mathrm{~b}$ & $32.6 \pm 4.62 \mathrm{a}$ & $44.6 \pm 1.05 \mathrm{a}$ & $646.0 \pm 16.58 \mathrm{~b}$ & 8.6 & 85 \\
\hline & Control & $52.0 \pm 2.03 \mathrm{a}$ & $506.0 \pm 3.61 \mathrm{a}$ & $28.2 \pm 8.58 \mathrm{a}$ & $44.8 \pm 0.61 \mathrm{a}$ & $590.2 \pm 15.42 \mathrm{a}$ & & \\
\hline \multirow[t]{8}{*}{2014} & MBT & $56.2 \pm 2.94 \mathrm{~b}$ & $463.8 \pm 10.43 b$ & $29.4 \pm 3.17 \mathrm{a}$ & $45.41 \pm 1.01 \mathrm{~b}$ & $508.0 \pm 76.21 \mathrm{ab}$ & 10.7 & 78 \\
\hline & MTT & $57.3 \pm 2.49 b$ & $469.6 \pm 11.46 \mathrm{~b}$ & $30.8 \pm 4.24 \mathrm{a}$ & $45.91 \pm 1.48 \mathrm{~b}$ & $539.2 \pm 36.27 \mathrm{~b}$ & 17.4 & 128 \\
\hline & EMB & $58.3 \pm 2.92 \mathrm{bc}$ & $459.6 \pm 30.44 \mathrm{~b}$ & $29.8 \pm 6.23 \mathrm{a}$ & $44.75 \pm 0.55 b$ & $503.0 \pm 21.96 \mathrm{ab}$ & 9.6 & 75 \\
\hline & IMI & $64.3 \pm 2.75 \mathrm{~d}$ & $464.6 \pm 13.61 \mathrm{~b}$ & $30.1 \pm 4.25 \mathrm{a}$ & $45.12 \pm 0.99 \mathrm{~b}$ & $515.0 \pm 53.50 \mathrm{ab}$ & 12.2 & 80 \\
\hline & BT & $59.9 \pm 2.91 \mathrm{c}$ & $457.4 \pm 13.87 \mathrm{~b}$ & $28.3 \pm 4.78 \mathrm{a}$ & $42.61 \pm 1.42 \mathrm{a}$ & $467.0 \pm 26.01 \mathrm{a}$ & 1.7 & 13 \\
\hline & FIC & $58.9 \pm 2.59 \mathrm{bc}$ & $473.0 \pm 8.19 \mathrm{~b}$ & $29.0 \pm 4.16 \mathrm{a}$ & $46.48 \pm 0.55 b$ & $541.6 \pm 40.26 b$ & 17.9 & 121 \\
\hline & IPR & $56.3 \pm 4.08 \mathrm{~b}$ & $486.0 \pm 5.57 \mathrm{c}$ & $29.1 \pm 5.47 \mathrm{a}$ & $45.22 \pm 0.38 \mathrm{~b}$ & $545.0 \pm 42.00 \mathrm{~b}$ & 18.7 & 126 \\
\hline & Control & $52.0 \pm 2.36 \mathrm{a}$ & $440.2 \pm 15.40 \mathrm{a}$ & $28.2 \pm 4.16 \mathrm{a}$ & $40.86 \pm 1.22 \mathrm{a}$ & $459.0 \pm 22.47 \mathrm{a}$ & & \\
\hline
\end{tabular}

\footnotetext{
${ }^{\mathrm{w}}$ Mean \pm standard deviation of the mean. The same letter within a column for each year indicates no significant difference at $P \leq 0.05$.

${ }^{x}$ Number of filled grains per panicle.

y Thousand kernel weight.

${ }^{\mathrm{z}}$ Additional income from wheat yields in 0.067 ha field after subtracting the expense of the seed treatments $(\mathrm{CNY}=\mathrm{Chinese}$ Yuan).
} 
higher than that of the untreated control. The increase rate for BT was the lowest at $8.6 \%$. In 2014, IPR, FIC, and MTT most effectively achieved grain yield increases, with grain yields of 545, 541, and $539 \mathrm{~g} \mathrm{~m}^{-2}$, respectively, and increase rates of 18.7, 17.9, and $17.4 \%$, which were significantly higher than those for the other treatments. The value of the grain produced from the MTT-treated seeds was the highest, with a mean additional gross income from grain sales of $128 \mathrm{CNY}$ per 0.067 ha. API and FIC also resulted in high additional gross incomes from grain sales of 126 and $121 \mathrm{CNY}$ per 0.067 ha, respectively. Nevertheless, no significant differences in net income were observed among IPR, FIC, and MTT. The increase rate for the BT plots was only $1.7 \%$, and the net income was the lowest at $13 \mathrm{CNY}$ per 0.067 ha. Although the increase rate for IMI was $12.2 \%$, the net profit was significantly lower compared with the other treatments due to the high cost of the commercial seed treatment (Table 2).

Overall, MTT reduced the populations of cysts and eggs by 60.7 and $28.8 \%$ relative to the control and decreased the population of Pratylenchus spp. by $30.0 \%$; in addition, it increased the wheat yield by $17.1 \%$ (net income valued at $135 \mathrm{CNY}$ per 0.067 ha). Further, FIC reduced the populations of cysts and eggs by 62.0 and $26.6 \%$ relative to the control, decreased the population of Pratylenchus spp. by $29.3 \%$, and increased the wheat yield by $17.9 \%$ (net income valued at $121 \mathrm{CNY}$ per $0.067 \mathrm{ha}$ ).

\section{Discussion}

As CCNs are host specific, the rotation of wheat with noncereal crops has good potential for reducing nematode densities. However, Pratylenchus is largely polyphagous; therefore, there are far fewer rotational options for controlling these nematodes (Nicol and Rivoal 2007). This situation has resulted in an increased reliance on chemicals to control the mixed populations of nematodes. Accordingly, we sought to evaluate the efficacies of common pesticide seed coatings for wheat. In this study, the control efficacies of two newly developed compounds, MBT and MTT, and five common chemicals on wheat nematodes in China were assessed. There are many benefits associated with the soil application of chemicals, as opposed to the foliar application, such as a decreased risk of exposure of workers and a reduced impact on aboveground beneficial insects (Qiao et al. 2012).

MBT is a volatile, water-insoluble, organic thiocyanic compound. In China, $4.2 \%$ MBT emulsifiable concentrate has been used as a seed treatment for controlling rice nematode disease caused by Aphelenchoides besseyi for a decade (Ye and Zhou 1994). Notably, the mortality of J2s of Meloidogyne spp. has been reported to be over $97 \%$ and the inhibition of egg hatching has been demonstrated to be over $94 \%$ following treatment with $4.2 \%$ MBT EC at $1.25 \mathrm{mg}$ a.i. liter $^{-1}$ (Qi et al. 2006). A decrease in the number of Meloidogyne juveniles has also been reported after treatment with $1 \mu \mathrm{g} \mathrm{ml}{ }^{-1}$ MBT for $10 \mathrm{~min}$ (Qi et al. 2008). Additional studies have revealed that MBT significantly decreases the germination rate of rice seeds compared with that of controls (Dai et al. 2012). MBT has also been tested on H. avenae, resulting in a reduction rate of $53 \%$ for cysts and an increase in wheat yields of $16.4 \%$ (Hao et al. 2014). In the present study, MBT was tested on different nematode species and populations.

MTT is a neonicotinoid insecticide that has an excellent and longlasting activity against underground pests when applied as a seed treatment (Maienfisch et al. 2001). Notably, in the field trials conducted from 2012 to 2015 , although we readily observed that the MBT and MTT seed coatings delayed wheat germination by 3 to 5 days, the seedlings were robust, and tillering was increased. Taking all of these factors into consideration, MTT was the most effective among the tested chemicals. Nevertheless, Smiley et al. (2012) reported that the wheat emergence rate was reduced after MTT treatment and that the mean added value of grain achieved with the MTT and MTT + abamectin treatments was far less than that of wheat produced in aldicarb-treated soil. We inferred that the differences between these results were due to differences in the dosages and formulations of the pesticides used. Controlling the pesticide dosage is very important to avoid phytotoxicity.

Field plots planted with seeds treated with both fipronil (5.0 $\mathrm{g}$ a.i. $100 \mathrm{~kg}^{-1}$ seed) and MTT (39.0 g a.i. $100 \mathrm{~kg}^{-1}$ seed) have been demonstrated to have $83 \%$ fewer Limonius californicus and Hypnoidus bicolor wireworms during the following year compared with untreated check plots (Morales-Rodriguez and Wanner 2015). Fipronil is a member of the phenylpyrazole insecticide class, and its mode of action involves blockage of GABA-gated chloride channels (Scharf and Siegfried 1999). The pesticide FIC, which contains 3\% fipronil and $15 \%$ chlorpyrifos, was developed for the control of soil insect grubs and cutworms. Its control efficacy against peanut white grubs has been reported to be $95 \%$, with chlorpyrifos residues at concentrations of lower than $0.019 \mathrm{mg} / \mathrm{kg}$ and fipronil residues at concentrations of lower than $0.0049 \mathrm{mg} / \mathrm{kg}$ (Yang et al. 2012). At a ratio of 1:100 to 1:50 (weight of formulation:weight of seeds), FIC application as a seed treatment to peanuts has been reported to effectively

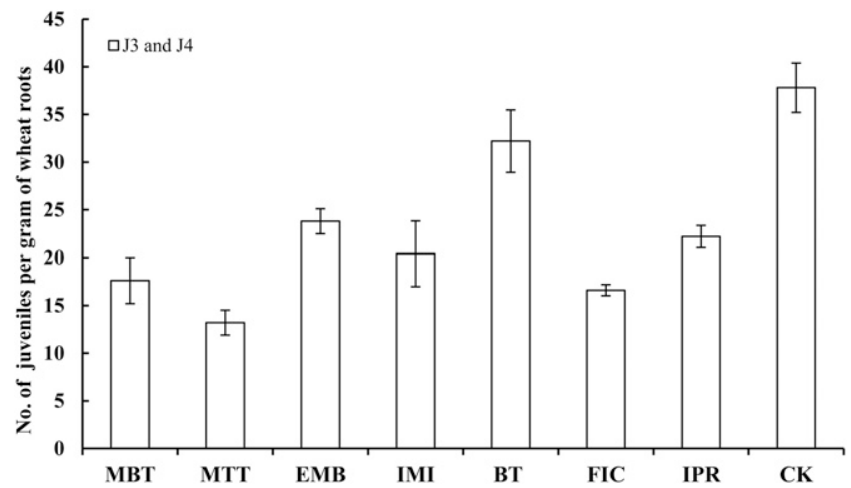

Fig. 1. Effects of seed treatments on third- and fourth-stage juveniles in roots of H. filipjevi in 2014. Each point represents the mean of 10 replicates; the vertical bars indicate the standard deviation of the mean.

Table 4. Effects of seed treatments on eggs from cysts in fields naturally infested with $H$. avenae and $H$. filipjevi ${ }^{\mathrm{y}}$

\begin{tabular}{|c|c|c|c|c|c|c|c|c|}
\hline \multirow[b]{2}{*}{ Treatment } & \multicolumn{3}{|c|}{ H. avenae } & \multirow[b]{2}{*}{ ROC (\%) } & \multicolumn{3}{|c|}{ H. filipjevi } & \multirow[b]{2}{*}{$\operatorname{ROC}(\%)$} \\
\hline & Seeding time & Harvesting time & $\overline{\text { RF }}$ & & Seeding time & Harvesting time & $\overline{\text { RF }}$ & \\
\hline MBT & $304.4 \pm 36.87 \mathrm{a}$ & $273.6 \pm 40.45 \mathrm{a}$ & 0.89 & 26.02 & $358.0 \pm 42.75 \mathrm{a}$ & $294.0 \pm 56.92 \mathrm{a}$ & 0.82 & 28.98 \\
\hline MTT & $313.8 \pm 19.97 \mathrm{a}$ & $267.0 \pm 48.12 \mathrm{a}$ & 0.85 & 27.80 & $369.0 \pm 69.49 a$ & $291.0 \pm 19.30 \mathrm{a}$ & 0.79 & 29.72 \\
\hline EMB & $314.6 \pm 36.83 \mathrm{a}$ & $309.2 \pm 14.32 \mathrm{a}$ & 0.98 & 16.26 & $342.0 \pm 63.71 \mathrm{a}$ & $304.4 \pm 31.33 \mathrm{ab}$ & 0.89 & 26.57 \\
\hline IMI & $304.8 \pm 7.19 \mathrm{a}$ & $316.6 \pm 33.05 \mathrm{a}$ & 1.04 & 14.36 & $333.8 \pm 37.84 \mathrm{a}$ & $318.6 \pm 57.49 \mathrm{ab}$ & 0.95 & 23.19 \\
\hline BT & $307.6 \pm 12.09 \mathrm{a}$ & $331.0 \pm 41.25 \mathrm{a}$ & 1.08 & 10.29 & $355.4 \pm 55.89 \mathrm{a}$ & $362.2 \pm 54.64 \mathrm{bc}$ & 1.02 & 12.56 \\
\hline FIC & $\mathrm{nt}^{\mathrm{z}}$ & $\mathrm{nt}$ & nt & nt & $367.8 \pm 59.60 \mathrm{a}$ & $304.6 \pm 36.83 \mathrm{ab}$ & 0.83 & 26.57 \\
\hline API & $\mathrm{nt}$ & $\mathrm{nt}$ & $\mathrm{nt}$ & $\mathrm{nt}$ & $358.6 \pm 66.56 a$ & $319.2 \pm 14.32 \mathrm{ab}$ & 0.89 & 22.95 \\
\hline Control & $308.6 \pm 17.63 \mathrm{a}$ & $369.6 \pm 32.69 \mathrm{~b}$ & 1.20 & & $369.4 \pm 32.53 \mathrm{a}$ & $414.4 \pm 19.50 \mathrm{c}$ & 1.12 & \\
\hline
\end{tabular}

\footnotetext{
${ }^{\mathrm{y}}$ Mean \pm standard deviation of the mean. The same letter within a column indicates no significant difference at $P \leq 0.05$.
}

${ }^{\mathrm{z}}$ Not tested. 
Table 5. Effects of seed treatments on a population of Pratylenchus spp. in rhizosphere-soil ${ }^{\mathrm{x}}$

\begin{tabular}{|c|c|c|c|c|c|c|}
\hline \multirow[b]{2}{*}{ Year } & \multirow[b]{2}{*}{ Treatment } & \multicolumn{4}{|c|}{ Number of Pratylenchus spp in rhizosphere-soil $(200 \mathrm{ml})$} & \multirow[b]{2}{*}{$\operatorname{ROC}(\%)$} \\
\hline & & Seeding time & Feekes 5.0y & Feekes $10.3^{z}\left(P_{f}\right)$ & $\overline{\mathbf{R F}}$ & \\
\hline \multirow[t]{6}{*}{2013} & MBT & $833.3 \pm 38.19 \mathrm{a}$ & $1,701.7 \pm 77.51 \mathrm{bc}$ & $2,490.0 \pm 15.57 \mathrm{c}$ & 2.99 & 21.87 \\
\hline & MTT & $866.7 \pm 38.18 \mathrm{a}$ & $1,678.3 \pm 17.56 \mathrm{ab}$ & $2,342.7 \pm 16.10 b$ & 2.70 & 26.51 \\
\hline & EMB & $873.3 \pm 68.98 \mathrm{a}$ & $1,608.3 \pm 52.04 \mathrm{a}$ & $2,290.0 \pm 17.95 \mathrm{a}$ & 2.62 & 28.14 \\
\hline & IMI & $888.3 \pm 37.53 \mathrm{a}$ & $1,633.3 \pm 20.82 \mathrm{ab}$ & $2,730.0 \pm 16.00 \mathrm{~d}$ & 3.07 & 14.33 \\
\hline & BT & $885.0 \pm 40.93 a$ & $1,773.3 \pm 22.54 \mathrm{c}$ & $3,126.7 \pm 25.17 \mathrm{e}$ & 3.53 & 1.88 \\
\hline & Control & $803.3 \pm 25.66 \mathrm{a}$ & $1,783.3 \pm 52.04 \mathrm{c}$ & $3,186.7 \pm 15.72 \mathrm{e}$ & 3.97 & \\
\hline \multirow[t]{8}{*}{2014} & MBT & $1,810.0 \pm 60.62 \mathrm{a}$ & $3,430.7 \pm 38.66 \mathrm{~cd}$ & $4,410.0 \pm 15.00 \mathrm{~b}$ & 2.43 & 30.55 \\
\hline & MTT & $1,870.0 \pm 42.72 \mathrm{a}$ & $3,080.0 \pm 70.00 \mathrm{a}$ & $4,230.0 \pm 10.00 \mathrm{a}$ & 2.26 & 33.38 \\
\hline & EMB & $1,806.7 \pm 51.32 \mathrm{a}$ & $3,306.7 \pm 45.09 \mathrm{bc}$ & $4,180.0 \pm 16.71 \mathrm{a}$ & 2.31 & 34.17 \\
\hline & IMI & $1,825.0 \pm 50.00 \mathrm{a}$ & $3,420.0 \pm 63.8 \mathrm{~cd}$ & $5,550.0 \pm 11.32 \mathrm{c}$ & 3.04 & 12.59 \\
\hline & BT & $1,810.0 \pm 73.65 \mathrm{a}$ & $3,476.3 \pm 25.8 \mathrm{~cd}$ & $5,983.3 \pm 15.75 \mathrm{~d}$ & 3.31 & 5.78 \\
\hline & FIC & $1,880.0 \pm 26.74 \mathrm{a}$ & $3,253.0 \pm 81.44 \mathrm{~b}$ & $4,490.0 \pm 12.91 \mathrm{~b}$ & 2.39 & 29.29 \\
\hline & IPR & $1,833.0 \pm 40.80 \mathrm{a}$ & $3,600.0 \pm 87.18 \mathrm{e}$ & $5,010.0 \pm 20.00 b c$ & 2.73 & 21.10 \\
\hline & Control & $1,877.3 \pm 70.12 \mathrm{a}$ & $4,216.3 \pm 25.8 \mathrm{f}$ & $6,350.0 \pm 26.14 \mathrm{e}$ & 3.39 & \\
\hline
\end{tabular}

x Mean \pm standard deviation of the mean. The same letter within a column for each year indicates no significant difference at $P \leq 0.05$.

${ }^{y}$ Wheat crop in terms of the Feekes growth scale, Feekes $5.0=$ leaf sheaths strongly erect.

${ }^{\mathrm{z}}$ Wheat crop in terms of the Feekes growth scale, Feekes $10.3=$ heading $1 / 2$ complete.

control peanut grub during the growth period, with a control rate of above $70 \%$ (Kong et al. 2014). Thus, fipronil may be effective for use against underground pests and soilborne pathogens (Kong et al. 2014; Xu et al. 2012). Chlorpyrifos (40\% EC, a.i.) has been shown to have ideal preventive and control efficacies against root knot nematodes in the potted ficus, with an $\mathrm{LD}_{50}$ of $0.22 \mathrm{mg} \mathrm{liter}^{-1}$ (Yu et al. 2011). In the present study, FIC showed good control efficacies on Pratylenchus spp. and Heterodera spp. cysts and eggs. These positive effects indicated that FIC could be effectively used as a nematicide against Heterodera spp. and Pratylenchus spp. Thus, taking the nematode lethality rate and wheat yield net income rate into consideration, MTT and FIC are suitable for controlling nematodes on wheat under natural field conditions. MBT showed good efficacy on $H$. avenae and Pratylenchus spp., but the wheat yield increase was arguably less than those achieved with MTT and FIC.

IPR is a dicarboximide fungicide that is similar in structure to the antiandrogens V and P (Leroux et al. 1992; Wolf et al. 1999). The target of dicarboximide fungicides could be a plasma membranebound NADPH-dependent flavin enzyme, the inhibition of which would initiate pathological oxidative processes. Moore and Lawrence (2010) reported that IPR significantly reduced a population of $M$. incognita on tomato and that it increased the marketable fruit weight. Chen (2015) applied for a patent for a novel product containing the effective components of IPR; this product possesses good efficacy on root knot nematodes and other cyst nematode species. Currently, there is no information available on the effects of IPR on CCNs. In the present study, we found that $50 \%$ IPR (SC) reduced cyst and egg reproduction, with an ROC value of $55.8 \%$. Additionally, IPR had good efficacy for increasing wheat yields.

EMB is a semisynthetic avermectin insecticide that has been used as a nematicide in greenhouses for many years in China. Pot experiments have shown that EMB is very effective for controlling $M$. incognita, with relative control efficacies of 94 and $80 \%$ when it is diluted by factors of 500 and 1,000 (Ding et al. 2009). An EMB + carbendazim + thiram $(20.5 \%)$ suspension concentrate for seed dressing has been registered for the treatment of soybean cyst nematodes and root rot in China. Hao et al. (2014) have reported greater control of $H$. avenae with an increase in the EMB dosage. In our investigation, we found that EMB was able to control Pratylenchus spp., with an ROC value of $31.2 \%$. In addition, the control efficacies of EMB on eggs and cysts of $H$. avenae were 16.3 and $57.1 \%$, and those on eggs and cysts of $H$. filipjevi were 26.6 and $57.3 \%$, respectively.

IMI is a systemic nitroguanidine insecticide that belongs to the neonicotinoid family. As an antagonist of the acetylcholine receptor, it is a highly effective insecticide with low mammalian toxicity that is used for the control of sucking insects, such as aphids, leafhoppers, and planthoppers, as well as for the control of nematodes (Elbert et al. 1990). IMI has been reported to exhibit good efficacy at $0.52 \mathrm{~g} \mathrm{liter}^{-1}$ (750 $\mathrm{g} \mathrm{kg}^{-1} \mathrm{WP}$ ) on Aphelenchoides fragariae, with a $77.2 \%$ decrease in the population reported at 45 days after treatment (Jagdale and Grewal 2002). Due to its excellent systemic characteristics, this product is especially appropriate for seed treatment and provides long-lasting protection. IMI is most commonly used in seed coatings in China to suppress damage due to soil insects, wheat aphids, and other pests. In the present trials, we found that IMI strongly increased wheat production, with ROC values for $H$. avenae and $H$. filipjevi cysts of 47.6 and $53.6 \%$.

BT produces toxic crystal proteins that disrupt host cellular functions, and Bacillus nematocida secretes a neutral protease (designated Bae16) that targets nematodes' essential intestinal proteins (Niu et al. 2010). In contrast with insecticides applied to the phylloplane, BT used as a nematicide is applied to soil. In our trials performed from 2013 to 2015 , BT was the least effective in controlling RLNs and CCNs, with similar low yield increases observed over the 2 years. BT may need to be improved for use in the control of soilborne pathogens and soil nematodes, or it may need to be combined with effective chemicals. Further experimentation is required to enhance the colonization of BT in soil, which could potentially provide continued protection from nematode invasion and significantly improve the biocontrol efficacy of this soil nematicide (Yu et al. 2015).

In general, the $\mathrm{CCN}$ population densities found in China are higher than those reported in other countries where CCNs are recognized as being economically damaging to wheat. The wheat yield reduction caused by nematodes in China has been estimated to be 1.2 million tons, valued at CNY 1.9 billion (Peng et al. 2009). Controlling CCNs is of major economic importance to the agricultural industry of China, and the sooner that $\mathrm{CCNs}$ are treated, the easier they will be controlled at lower costs. In Henan Province, which is the largest wheat-producing province in China, CCNs infest more than 1.2 million ha of wheat fields each year (Peng et al. 2009). The current study has provided evidence that the coating of wheat seeds with the nematicides MTT and FIC effectively reduces the number of cysts, suppresses the reproduction of CCNs and RLNs, and consequently enhances wheat yields. The results obtained in this study are highly encouraging and indicate that these compounds are promising alternatives for the control of CCNs in wheat under natural field conditions.

\section{Acknowledgments}

This study was financially supported by the Special Fund for Agro-scientific Research in the Public Interest (201503114 and 200903040) and the National Key Basic Research Program of China (973 Program, 2013CB127502). We are truly grateful to Prof. Mark Gleason (Iowa State University, USA) for providing scientific advice and for revising the manuscript. 


\section{Literature Cited}

Becker, J. O., and Ploeg, A. 2012. Evaluation of novel products for root-knot nematode management in tomato, 2011. Plant Dis. Manag. Rep. 6:N016.

Becker, J. O., and Ploeg, A. 2013. Efficacy of nematicides for root knot nematode management in tomato, 2012. Plant Dis. Manag. Rep. 7:N009.

Bi, Q. Y., Ma, Z. Q., Han, X. Y., Zhang, X. F., Wang, W. Q., and Zhao, J. J. 2014. Control effect of five kinds of seed coating formulations on soil-borne diseases in wheat. Plant Prot. 40:171-176.

Byrd, D., Kirkpatrick, T., and Barker, K. R. 1983. An improved technique for clearing and staining plant tissues for detection of nematodes. J. Nematol. 15:142-143.

Chen, J. 2015. One novel effective combination compounds on nematode. Patent Number: CN 104839226 A.

Cheng, X., Liu, X., Wang, H., Ji, X., Wang, K., Wei, M., and Qiao, K. 2015. Effect of emamectin benzoate on root-knot nematodes and tomato yield. PLoS One 10:e0141235.

Cui, J., Huang, W., Peng, H., Liu, S., Wang, G., Kong, L., and Peng, D. 2015. A new pathotype characterization of Daxing and Huangyuan populations of cereal cyst nematode (Heterodera avenae) in China. J. Integr. Agric. 14:724-731.

Dai, L., Zhang, D., Li, H., Yu, L., Wang, W., and Ye, Z. 2012. Effect of different fungicides on teliospore germination of Tilletia barclayana. Plant Quar. 26:1-4.

Devidas, P., and Rehberger, L. A. 1992. The effects of exotoxin (thuringiensin) from Bacillus thuringiensis on Meloidogyne incognita and Caenorhabditis elegans. Plant Soil 145:115-120.

Ding, X., Liang, R., and Wang, X. 2009. Toxicity and control efficacy of emamectin benzoate to the root-knot nematode Meloidogyne incognita as well as its safety to tomato. J. Nanjing Agric. Univ. 32:85-88.

Dungan, R. S., Ibekwe, A. M., and Yates, S. R. 2003. Effect of propargyl bromide and 1,3-dichloropropene on microbial communities in an organically amended soil. FEMS Microbiol. Ecol. 43:75-87.

Elbert, A., Overbeck, H., Iwaya, K., and Tsuboi, S. 1990. Imidacloprid, a novel systemic nitromethylene analogue insecticide for crop protection. Pages 21-28 in: Proc. Brighton Crop Protection Conference, Pests and Diseases. British Crop Protection Council, Alton, U.K.

Graeff-Teixeira, C., Medeiros, E., Zanini, G., Brasil, C., Cardozo, B., Dalpiaz, M., and Bisol, L. 1997. Inexpensive alternative material for the isolation of larvae with the Baermann method. Mem. Inst. Oswaldo Cruz 92:399-400

Hajihasani, A., Nicol, J., Rezaee, S., and Tanha Maafi, Z. 2010. Effect of the cereal cyst nematode, Heterodera filipjevi, on wheat in microplot trials. Nematology 12:357-363.

Hao, R., Huang, W. K., Liu, C., Peng, D. L., Li, H. M., and Li, H. X. 2014. Effect of seed-coatings on controlling cereal cyst nematode (Heterodera avenae) of wheat. Plant Prot. 40:182-186.

Haydock, P. P. J., Woods, S. R., Grove, I. G., and Hare, M. C. 2006. Chemical control of nematodes. Pages 392-408 in: Plant Nematology. R. N. Perry and M. Moens, eds. CAB Intl, Wallingford, U.K.

Hou, S. Y., Wang, A. L., Zhang, G., and Huang, L. L. 2012. Effect of cereal cyst nematode on agronomic characteristics and yield losses of spring wheat. J. Agric. 2:31-36.

Jagdale, G. B., and Grewal, P. S. 2002. Identification of alternatives for the management of foliar nematodes in floriculture. Pest Manag. Sci. 58:451-458.

Kearn, J., Ludlow, E., Dillon, J., O'Connor, V., and Holden-Dye, L. 2014. Fluensulfone is a nematicide with a mode of action distinct from anticholinesterases and macrocyclic lactones. Pestic. Biochem. Physiol. 109:44-57.

Kong, D., Yuan, H., Yan, X., and Yang, D. 2014. Study on the control of Fipronil.Chlorpyrifos 18\% against peanut grub (Holotrichia parallella). Pestic. Sci. Admin. 35:60-63.

Leroux, P., Lanen, C., and Fritz, R. 1992. Similarities in the antifungal activities of fenpiclonil, iprodione and tolclofos-methyl against Botrytis cinerea and Fusarium nivale. Pestic. Sci. 36:255-261.

Maienfisch, P., Angst, M., Brandl, F., Fischer, W., Hofer, D., Kayser, H., Kobel, W., Rindlisbacher, A., Senn, R., Steinemann, A., and Widmer, H. 2001. Chemistry and biology of thiamethoxam: A second generation neonicotinoid. Pest Manag. Sci. 57:906-913.

Mao, X. F., Li, H. X., Chen, X. Y., and Hu, F. 2004. Extraction efficiency of soil nematodes by different methods. Chin. J. Ecol. 23:149-151.

Miller, T. D. 1999. Growth stages of wheat: identification and understanding improve crop management. Texas Agricultural Extension Service, the Texas A\&M University System. SCS-1999-16.

Mohammed, S. H., El Saedy, M. A., Enan, M. R., Ibrahim, N. E., Ghareeb, A., and Moustafa, S. A. 2008. Biocontrol efficiency of Bacillus thuringiensis toxins against root-knot nematode, Meloidogyne incognita. J. Cell Mol. Biol. 7:57-66.

Moore, S. R., and Lawrence, K. S. 2010. Evaluation of iprodione for control of root-knot nematodes on tomato in south Alabama, 2009. Plant Dis. Manag. Rep. 4:N012.
Morales-Rodriguez, A., and Wanner, K. W. 2015. Efficacy of thiamethoxam and fipronil, applied alone and in combination, to control Limonius californicus and Hypnoidus bicolor (Coleoptera: Elateridae). Pest Manag. Sci. 71:584-591.

Nicol, J. M., and Rivoal, R. 2007. Global knowledge and its application for the integrated control and management of nematodes on wheat. Pages 251-294 in: Integrated Management and Biocontrol of Vegetable and Grain Crop Nematodes. A. Ciancio and K. G. Mukerji, eds. Springer Verlag, Dordrecht, The Netherlands.

Nicol, J. M., Turner, S. J., Coyne, D. L., den Nijs, L., Hockland, S., and Maafi, Z. T. 2011. Current nematode threats to world agriculture. Pages 21-43 in: Genomics and Molecular Genetics of Plant-Nematode Interactions. J. T. Jones, G. Gheysen, and C. Fenoll, eds. Springer Verlag, Heidelberg, Germany.

Niu, Q., Huang, X., Zhang, L., Xu, J., Yang, D., Wei, K., Niu, X., An, Z., Bennett, J. W., Zou, C., Yang, J., and Zhang, K. 2010. A Trojan horse mechanism of bacterial pathogenesis against nematodes. Proc. Natl Acad. Sci. 107: 16631-16636.

Peng, D. L., Nicol, J. M., Li, H. M., Hou, S. Y., Li, H. X., Chen, S. L., Ma, P., Li, H., and Riley, I. T. 2009. Current knowledge of cereal cyst nematode (Heterodera avenae) on wheat in China. Pages 29-34 in: Cereal Cyst Nematodes: Status, Research and Outlook. I. T. Riley, J. M. Nicol, and A. A. Dababat, eds. International Maize and Wheat Improvement Center, Ankara, Turkey.

Peng, D. L., Ye, W. X., Peng, H., and Gu, X. C. 2010. First report of the cyst nematode (Heterodera filipjevi) on wheat in Henan Province, China. Plant Dis. $94: 1262$.

Peng, H., Li, X., Cui, J. K., Peng, D. L., Huang, W. K., He, W. T., and Kong, L. A. 2016. First report of cereal cyst nematode, Heterodera filipjevi, on wheat from Anhui Province, China. Plant Dis. 100:536.

Qi, Z., Chen, C., Wang, J. X., and Zhou, M. G. 2008. Mode of action of methylene bis thiocyanate and its decomposition products to Meloidogyne spp. juveniles. Acta Phytopathol. Sin. 38:420-424.

Qi, Z., Wang, J. X., Chen, C. J., and Zhou, M. G. 2006. Efficacy of the methylene bisthiocyanate formulation, $4.2 \% \mathrm{MBT}$ EC, as a potentially novel nematicide for the control of root-knot nematode. Austral. Plant Pathol. 35:733-737.

Qiao, K., Liu, X., Wang, H., Xia, X., Ji, X., and Wang, K. 2012. Effect of abamectin on root-knot nematodes and tomato yield. Pest Manag. Sci. 68:853-857.

Rich, J. R., Dunn, R. A., and Noling, J. W. 2004. Nematicides: Past and present uses. Nematology 2:1179-1200.

Riggs, R. D., Wrather, J. A., Mauromoustakos, A., and Rakes, L. 2000. Planting date and soybean cultivar maturity group affect population dynamics of Heterodera glycines, and all affect yield of soybean. J. Nematol. 32: 334-342.

Scharf, M. E., and Siegfried, B. D. 1999. Toxicity and neurophysiological effects of fipronil and fipronil sulfone on the western corn rootworm (Coleoptera: Chrysomelidae). Arch. Insect Biochem. Physiol. 40:150-156.

Smiley, R. W., Gourlie, J. A., Rhinhart, K. E. L., Marshall, J. M., Anderson, M. D., and Yan, G. 2012. Influence of nematicides and fungicides on spring wheat in fields infested with soil borne pathogens. Plant Dis. 96:1537-1547.

Vanstone, V. A., Hollaway, G. J., and Stirling, G. R. 2008. Managing nematode pests in the southern and western regions of the Australian cereal industry: Continuing progress in a challenging environment. Austral. Plant Pathol. 37: 220-234.

Wolf, C., Lambright, C., Mann, P., Price, M., Cooper, R. L., Ostby, J., and Gray, L. E. 1999. Administration of potentially antiandrogenic pesticides (procymidone, linuron, iprodione, chlozolinate, $\mathrm{p}, \mathrm{p}^{\prime}$-DDE, and ketoconazole) and toxic substances (dibutyl-and diethylhexyl phthalate, PCB 169, and ethane dimethane sulphonate) during sexual differentiation produces diverse profiles of reproductive malformations in the male rat. Toxicol. Ind. Health 15:94-118.

Xu, H. K., Zou, M., and Cao, Z. H. 2012. Controlling soil insect and nematode using one novel granules. Patent Number: CN102771503A.

Ye, Z. Y., and Zhou, M. G. 1994. Efficacy and application of TH-88 to seed borne diseases of rice and wheat or barley. Plant Prot. Tech. Ext. 1:11-12.

Yu, D. Y., Yao, J., Lan, Y., Huang, P., and Fang, D. L. 2011. The development and damage of root-knot nematode disease on the export potted ficus and its reagent selection for prevention and control. Chin. J. Trop. Crops. 32: 158-162.

Yu, Z., Xiong, J., Zhou, Q., Luo, H., Hu, S., Xia, L., Sun, M., Li, L., and Yu, Z. 2015. The diverse nematicidal properties and biocontrol efficacy of Bacillus thuringiensis Cry6A against the root-knot nematode meloidogyne hapla. J. Invertebr. Pathol. 125:73-80.

Yang, D. B., Yuan, H. Z., and Yan, X. J. 2012. One novel micro capsule of pesticide formulation. Patent Number: CN 102362590 A. 